\title{
RASSFIA promoter methylation correlates development, progression, and poor cancer- specific survival of renal cell carcinoma: trial sequential analysis
}

This article was published in the following Dove Medical Press journal: OncoTargets and Therapy

\author{
Qianfeng Zhuang* \\ Zhen Chen* \\ Jie Shen* \\ Min Fan \\ Dong Xue \\ Hao Lu \\ Renfang Xu \\ Xiaozhou $\mathrm{He}$ \\ Department of Urology, The Third \\ Affiliated Hospital of Soochow \\ University, Changzhou 213003, China \\ *These authors contributed equally \\ to this work
}

Correspondence: Xiaozhou He Department of Urology, The Third Affiliated Hospital of Soochow University, I85 Juqian Street, Changzhou 213003,

China

Tel +86 I8I 36392428

Email czyyhxz@I63.com

\begin{abstract}
Background: This meta-analysis evaluated the clinicopathologic and prognostic significance of RASSF1A promoter methylation in renal cell carcinoma (RCC).

Materials and methods: The ORs or HRs and their $95 \%$ CIs were calculated. Trial sequential analysis was conducted.

Results: Twenty-two articles that included 1,421 patients with RCC and 724 controls were identified. RASSF $1 A$ promoter methylation correlated with RCC in tissue, blood, and urine samples. On multivariate analysis, $R A S S F 1 A$ promoter methylation was associated with tumor grade (grade 3-4 vs 1-2: OR=3.59), clinical stage (stage 3-4 vs 1-2: OR=2.15), T classification (pT2-4 vs pT1: OR=2.66), histologic subtypes (papillary vs clear cell: $\mathrm{OR}=2.91$ ), and cancer-specific survival ( $\mathrm{HR}=1.78)$, but it was not linked to age, gender, lymph node status, distant metastasis, or overall survival. The Cancer Genome Atlas data also showed that RASSF 1A methylation was significantly more likely to be seen in papillary vs clear-cell RCC (OR=23.19).

Conclusion: RASSF1A promoter methylation may be associated with the development and progression of RCC, as well as poor cancer-specific survival. Methylation was more frequent in papillary vs clear-cell RCC. More studies are needed to confirm these findings in blood or urine samples.
\end{abstract}

Keywords: RAS association domain family protein 1A, methylation, survival, clinical features

\section{Introduction}

Renal cell carcinoma (RCC) is the most common malignant tumor affecting the kidneys, accounting for about $90 \%$ of kidney carcinomas. ${ }^{1}$ Approximately 63,990 new RCC cases were diagnosed in the USA in 2017, and these were associated with an estimated 14,400 deaths. ${ }^{2}$ There are two common histological subtypes of RCC. Clearcell RCC (ccRCC) is the most common, accounting for $70 \%-80 \%$ of all renal cancer cases. Papillary RCC (pRCC) represents another 10\%-20\% of cases. ${ }^{3,4}$ Approximately $25 \%-30 \%$ of patients with RCC present with advanced or metastatic disease, and the 5-year survival rate is poor. ${ }^{5}$

DNA methylation within the promoter regions is an important mechanism underlying epigenetic modifications, which may cause inactivation of gene expression and play a crucial role in the carcinogenesis, progression, and prognosis of various human cancers. ${ }^{6-8}$ Previous studies have suggested that promoter methylation of some cancerrelated genes is found in $\mathrm{RCC}$, such as $H O X B 13{ }^{9}$ and $C D K N 2 A / 2 B .{ }^{10} \mathrm{RASSF} 1 A$ is a key isoform of RASSF1 located on the chromosomal region $3 \mathrm{p} 21.3 .{ }^{11}$ An important 
tumor suppressor gene, $R A S S F 1 A$ is involved in cell cycle regulation, microtubule stabilization, cellular adhesion and motility, and cell apoptosis. ${ }^{12-14}$

RASSF $1 A$ promoter methylation has been reported in tissue, blood, and urine samples from patients with RCC. ${ }^{15-17}$ There are, however, inconsistent results regarding the level of RASSF1A promoter methylation in patients with RCC and controls. For example, Ellinger et al reported that the RASSF $1 A$ promoter had a similar methylation rate in $\mathrm{RCC}$ and adjacent normal tissue samples. ${ }^{18}$ In contrast, $R A S S F 1 A$ promoter methylation was more frequent in RCC than in adjacent normal tissue samples in a study by Loginov et al. ${ }^{19}$ With this background of conflicting results, we conducted a meta-analysis to assess differences in $R A S S F 1 A$ promoter methylation between RCC and control tissue, blood, and urine samples. Moreover, we evaluated the association of RASSF 1A promoter methylation with clinicopathologic features and prognosis in patients with RCC.

\section{Materials and methods}

\section{Search strategy}

A systematic literature search of the PubMed, EMBASE, EBSCO, Wanfang, and CNKI databases was conducted to identify eligible studies published through December 1, 2017, without any language restrictions. The following keywords and scientific search terms were used: (kidney OR renal) AND (cancer OR tumor OR neoplasm OR carcinoma) AND (methylation OR methylated OR hypermethylation OR epigene*) AND (RAS association domain family protein 1A OR RASSF1A OR RASSF1 OR RAS association domain family protein 1). We manually searched the relevant references from all eligible articles to find other potential publications.

\section{Selection criteria}

Articles that met the following inclusion criteria were selected for the meta-analysis: 1) patients were confirmed with adult RCC by histopathologic examination; 2) studies reported sufficient data to evaluate differences in RASSF1A promoter methylation between the RCC and control groups; 3) studies had sufficient data to assess the correlation of RASSF 1A promoter methylation with clinicopathologic features; and 4) studies provided enough survival data to evaluate the prognostic effect of $R A S S F 1 A$ promoter methylation in RCC. When multiple papers using the same patient population were published, the study with more information was included in the meta-analysis.

\section{Data extraction}

The following information was extracted from the included publications: surname of the first author, year of publication, country, ethnic population, cancer stage, mean or median age, sample type, detection method, histologic type, number of cases and controls, survival data with multivariate analysis, and clinicopathologic features such as age $(\geq 50$ vs $<50$ years), gender (male vs female), tumor grade (3-4 vs 1-2), clinical stage (3-4 vs 1-2), T classification (pT2-4 vs pT1), histologic subtypes (pRCC vs ccRCC), lymph node metastasis (yes vs no), and distant metastasis (yes vs no).

\section{The Cancer Genome Atlas (TCGA) dataset}

Clinical information for RCC, which included two sets of samples (methylation $450 \mathrm{~K}$ dataset: 275 pRCCs and 319 ccRCCs), was downloaded from the TCGA data portal (https://portal.gdc.cancer.gov/repository). The cutoff value of $R A S S F 1 A$ promoter methylation was set by its median value. The association between clinicopathologic characteristics and $R A S S F 1 A$ promoter methylation was analyzed using logistic regression (R; v.3.4.3). Multivariate Cox analysis was used to analyze the impact of $R A S S F 1 A$ promoter methylation on overall survival (R; v.3.4.3).

\section{Statistical analysis}

All data analyses were performed using Stata software 12.0 (StataCorp LP, College Station, TX, USA). Differences in RASSF 1A promoter methylation between RCC and control samples and the correlation of RASSF $1 A$ promoter methylation with the clinicopathologic characteristics of patients with RCC were calculated using pooled ORs and the corresponding 95\% CIs. Overall HRs with their 95\% CIs were also calculated to determine the prognostic role of $R A S S F 1 A$ promoter methylation, using multivariate analysis if possible. The Cochran's Q statistic was used to estimate possible heterogeneity among studies. ${ }^{20,21}$ A random-effects model was applied in the meta-analysis. When substantial heterogeneity was measured $(P<0.1)$, a sensitivity analysis was carried out to determine the influence of an individual study on the pooled OR and heterogeneity by deleting one study at a time..$^{22,23}$ For results covered by more than nine studies, possible publication bias was detected with Egger's test. ${ }^{24}$ We performed trial sequential meta-analyses (TSA) to reduce type I error and to calculate the estimated required sample size information. ${ }^{25,26}$ For significant results with more than one study, the type I error rate was set at 
$5 \%$ and the type II error rate was considered to be $20 \%$ (a statistical test power of $80 \%$ ). The relative risk reduction was set at $20 \%$ in the meta-analysis. If the cumulative Z-curve crossed the trial sequential monitoring boundary or the required information size, the statistical evidence was deemed conclusive. Otherwise, additional studies would be needed for a definitive result..$^{27,28}$

\section{Results}

\section{Study characteristics}

Figure 1 summarizes the details of the study selection procedure; 22 publications with a total of 1,421 patients with RCC and 724 controls fulfilled the inclusion criteria and were selected for the meta-analysis. ${ }^{15-19,29-45}$ Of the included publications, 15 assessed differences in RASSF $1 A$ promoter methylation between RCC and control samples using tissue samples and 6 used blood or urine samples. Sixteen studies evaluated the relationships between $R A S S F 1 A$ promoter methylation and the clinicopathologic characteristics of patients with RCC. Two studies reported information on survival in patients with RCC using multivariate analysis. The baseline characteristics of the included publications are presented in Tables 1 and S1.

\section{Correlation between RASSFIA promoter methylation and RCC in cancer vs control tissue samples}

In 15 studies that included the comparison of 829 patients with RCC and 467 adjacent/normal tissue samples (Figure 2), RASSF $1 A$ promoter methylation was notably higher in $\mathrm{RCC}$ than in adjacent/normal tissue samples $(\mathrm{OR}=5.64$, $95 \% \mathrm{CI}=1.82-17.51, P=0.003)$.

\section{Subgroup and sensitivity analyses in cancer vs control tissue samples}

We conducted subgroup analyses by ethnicity (Asians and Caucasians) and testing method (methylation-specific polymerase chain reaction [MSP] and non-MSP) (Table 2). In the ethnicity analysis, RASSF $1 A$ promoter methylation was associated with RCC in Caucasians $(\mathrm{OR}=4.90,95 \%$ $\mathrm{CI}=1.45-16.64, P=0.011)$, but not in Asians $(\mathrm{OR}=9.27,95 \%$ $\mathrm{CI}=0.35-243.63, P=0.182)$. In the testing method analysis, RASSF1A promoter methylation was associated with RCC in the MSP subgroup $(\mathrm{OR}=16.32,95 \% \mathrm{CI}=5.25-50.69$, $P<0.001)$, but not in the non-MSP subgroup ( $\mathrm{OR}=1.85$, $95 \% \mathrm{CI}=0.27-12.48, P=0.527)$.

Other studies by a manual search $(n=3)$ databases $(n=221)$
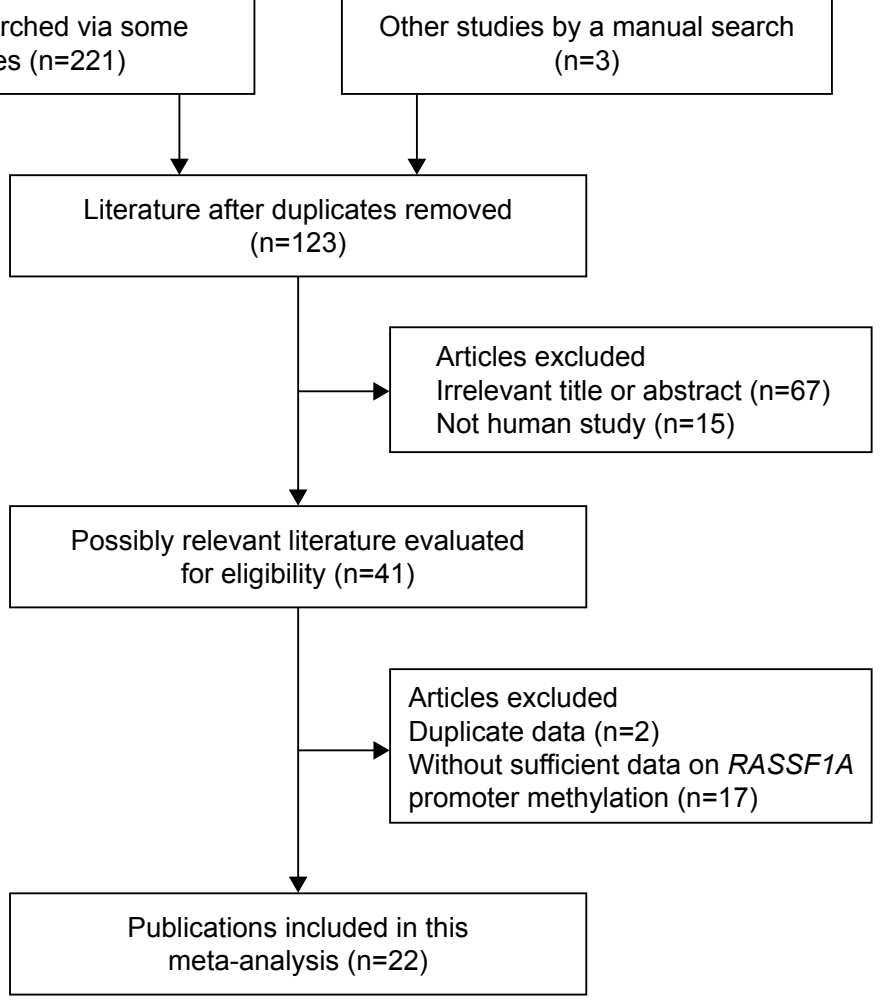

Figure I Flow diagram of the study selection procedure. 


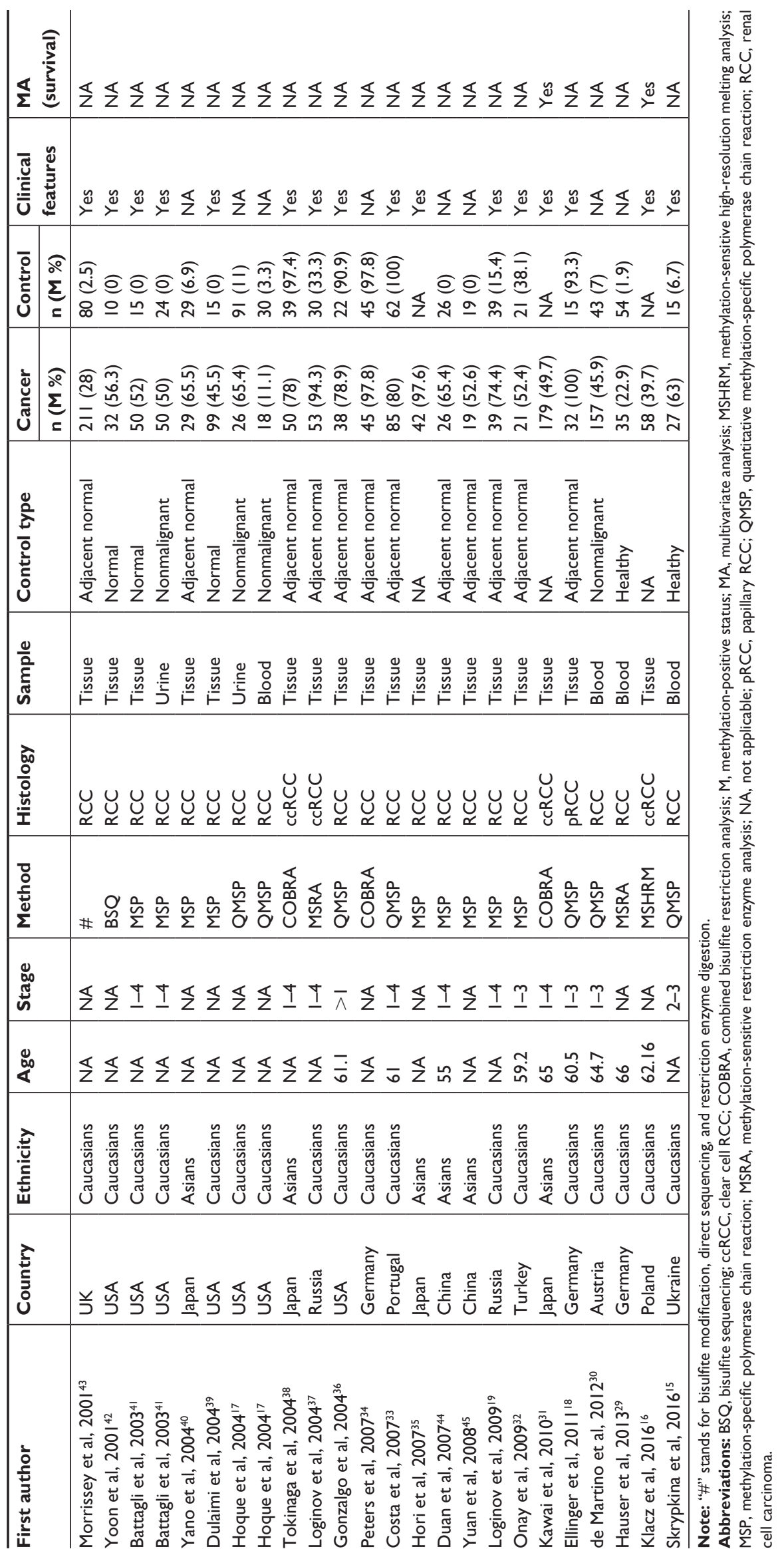




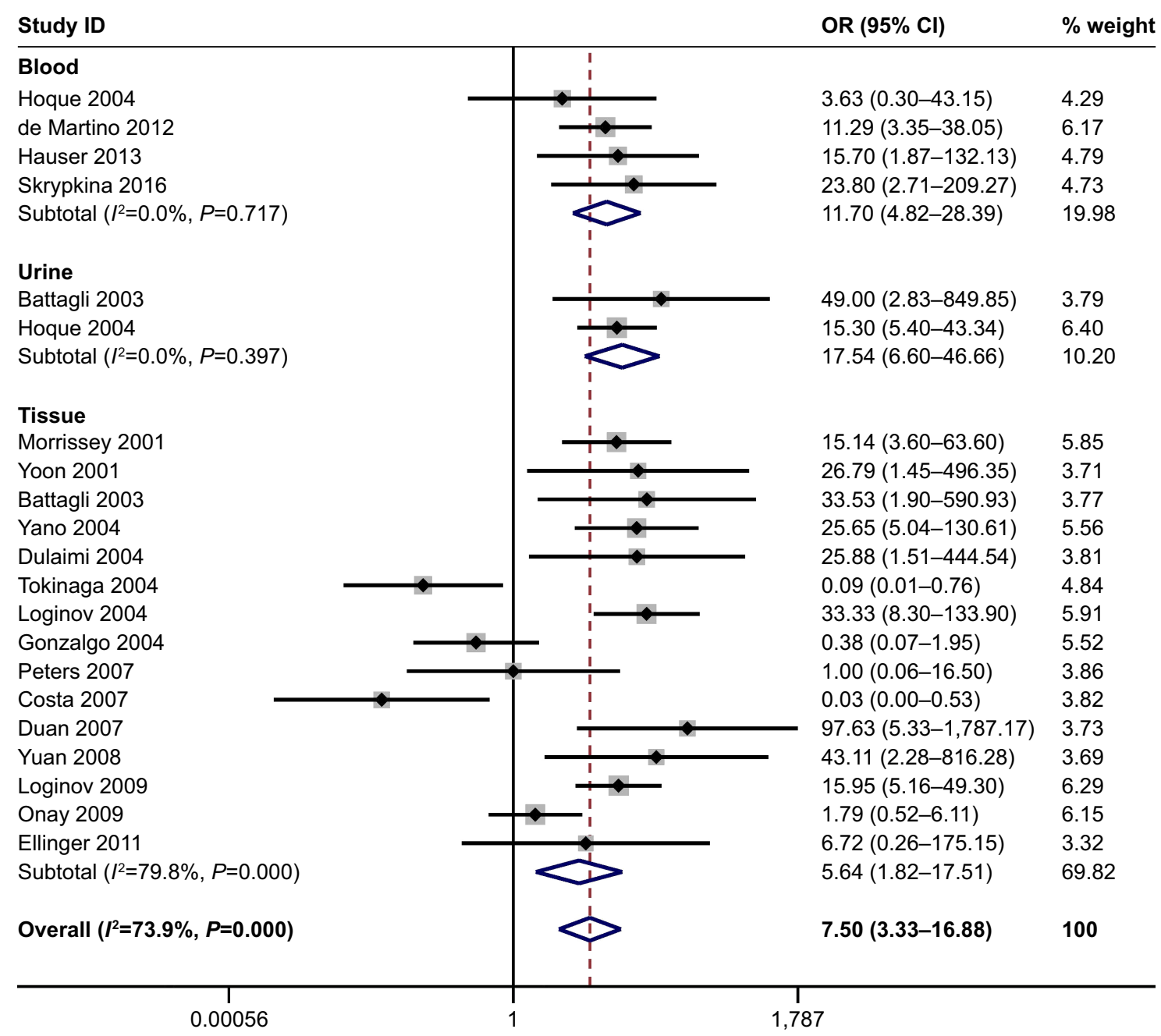

Figure 2 Forest plot of the association of $R A S S F I A$ promoter methylation in the $R C C$ vs control group using tissue: $O R=5.64,95 \% C l=I .82-\mid 7.5 I, P=0.003$; blood: $O R=I I .70$, 95\% $\mathrm{Cl}=4.82-28.39, P<0.00 \mathrm{I}$; and urine: $\mathrm{OR}=17.54,95 \% \mathrm{Cl}=6.60-46.66, P<0.00 \mathrm{I}$.

Note: Weights are from random-effects analysis.

Abbreviation: RCC, renal cell carcinoma.

There was evidence of significant heterogeneity in cancer vs control tissue samples, so we performed a sensitivity analysis. We successively removed four studies - Tokinaga et $\mathrm{al}^{38}$ in Japan, Costa et $\mathrm{al}^{33}$ in Portugal, Gonzalgo et $\mathrm{al}^{36}$ in the USA, and Onay et $\mathrm{al}^{32}$ in Turkey - and recalculated the overall OR (OR=19.78, 95\% CI=11.09-35.29, $P<0.001)$, resulting in no heterogeneity $(P=0.693)$.

\section{Correlation between RASSFIA promoter methylation and RCC in cancer vs control blood or urine samples}

In four studies that included the comparison of 237 patients with RCC with 142 nonmalignant blood samples, RASSF1A promoter methylation was significantly more likely in RCC than in nonmalignant blood samples $(\mathrm{OR}=11.70$,

Table 2 Subgroup analyses of RASSFIA promoter methylation in cancer vs control tissue samples

\begin{tabular}{l|l|l|l|l|l}
\hline Subgroup analyses & Pooled OR $(\mathbf{9 5 \%} \mathbf{C I})$ & Heterogeneity $(\boldsymbol{P})$ & $\boldsymbol{P}$-value & Cases & Controls \\
\hline Ethnicity & & & & & \\
$\quad$ Caucasians & $4.90(1.45-16.64)$ & $<0.001$ & 0.011 & 705 & 354 \\
$\quad$ Asians & $9.27(0.35-243.63)$ & $<0.001$ & 0.182 & 124 & 113 \\
Testing method & $1.85(0.27-12.48)$ & $<0.001$ & 0.527 & 546 & 303 \\
$\quad$ Non-MSP & $16.32(5.25-50.69)$ & 0.028 & $<0.001$ & 283 & 164 \\
MSP &
\end{tabular}

Abbreviation: MSP, methylation-specific polymerase chain reaction. 
95\% CI=4.82-28.39, $P<0.001$; Figure 2). In addition, in a comparison of 76 RCCs and 115 nonmalignant urine samples, RASSF $1 A$ promoter methylation was significantly higher in $\mathrm{RCC}$ than in nonmalignant urine samples $(\mathrm{OR}=17.54$, 95\% CI=6.60-46.66, $P<0.001$; Figure 2).

\section{Correlation of RASSFIA promoter} methylation with age and gender in RCC

Seven studies that included 321 patients with RCC demonstrated that RASSF $1 A$ promoter methylation was not correlated with age $(\mathrm{OR}=1.00,95 \% \mathrm{CI}=0.50-2.04, P=0.99$; Figure 3$)$. Eight studies that included 537 patients with RCC showed that $R A S S F 1 A$ promoter methylation was not correlated with gender $(\mathrm{OR}=0.95,95 \% \mathrm{CI}=0.51-1.76, P=0.86$; Figure 3$)$.

\section{Correlation of RASSFIA promoter} methylation with lymph node status and distant metastasis in RCC

In seven studies that included 438 patients with RCC, RASSF $1 A$ promoter methylation was not associated with lymph node metastasis $(\mathrm{OR}=1.72,95 \% \mathrm{CI}=0.76-3.87$,
$P=0.192$; Figure 4). Four studies that included 257 patients with RCC showed that there was no correlation between RASSF $1 A$ promoter methylation and distant metastasis $(\mathrm{OR}=1.66,95 \% \mathrm{CI}=0.75-3.69, P=0.21$; Figure 4).

Correlation of RASSFIA promoter methylation with tumor grade and clinical stage in RCC

In 13 studies that included 686 patients with RCC, a significant relationship was observed between $R A S S F 1 A$ promoter methylation and tumor grade $(\mathrm{OR}=3.59,95 \% \mathrm{CI}=1.85-6.95$, $P<0.001$; Figure 5). RASSF $1 A$ promoter methylation was also linked to clinical stage in eight studies that included 463 patients with $\mathrm{RCC}(\mathrm{OR}=2.15,95 \% \mathrm{CI}=1.34-3.45$, $P=0.001$; Figure 5).

\section{Correlation of RASSFIA promoter methylation with $T$ classification and histologic subtypes in RCC}

In seven studies that included 306 patients with RCC, a significant correlation was found between $R A S S F 1 A$

\begin{tabular}{|c|c|c|}
\hline Study ID & OR $(95 \% \mathrm{Cl})$ & $\%$ weight \\
\hline \multicolumn{3}{|l|}{ Age } \\
\hline Battagli 2003 & $1.10(0.24-4.99)$ & 5.87 \\
\hline Battagli 2003 & $1.00(0.22-4.54)$ & 5.88 \\
\hline Dulaimi 2004 & $1.39(0.42-4.60)$ & 9.00 \\
\hline Hori 2007 & $1.31(0.05-35.19)$ & 1.32 \\
\hline Onay 2009 & $0.50(0.04-6.55)$ & 2.14 \\
\hline Skrypkina 2016 & $0.36(0.03-3.79)$ & 2.55 \\
\hline Ellinger 2011 & (Excluded) & 0.00 \\
\hline Subtotal $\left(I^{2}=0.0 \%, P=0.931\right)$ & $1.00(0.50-2.04)$ & 26.75 \\
\hline \multicolumn{3}{|l|}{ Gender } \\
\hline Battagli 2003 & $0.53(0.16-1.80)$ & 8.73 \\
\hline Battagli 2003 & $0.47(0.14-1.60)$ & 8.70 \\
\hline Dulaimi 2004 & $0.91(0.39-2.08)$ & 16.50 \\
\hline Hori 2007 & $1.14(0.04-30.34)$ & 1.33 \\
\hline Kawai 2010 & $1.73(0.89-3.35)$ & 23.14 \\
\hline Klacz 2016 & $0.43(0.15-1.26)$ & 10.79 \\
\hline Skrypkina 2016 & $7.33(1.16-46.23)$ & 4.06 \\
\hline Ellinger 2011 & (Excluded) & 0.00 \\
\hline Subtotal $\left(I^{2}=50.1 \%, P=0.062\right)$ & $0.95(0.51-1.76)$ & 73.25 \\
\hline Overall & & 100 \\
\hline 0.0216 & & \\
\hline
\end{tabular}

Figure 3 Forest plot of the association of $R A S S F I A$ promoter methylation with age $(O R=I .00,95 \% C l=0.50-2.04, P=0.99)$ and gender $(O R=0.95,95 \% C l=0.5 I-I .76, P=0.86)$ in RCC.

Note: Weights are from random-effects analysis.

Abbreviation: RCC, renal cell carcinoma. 


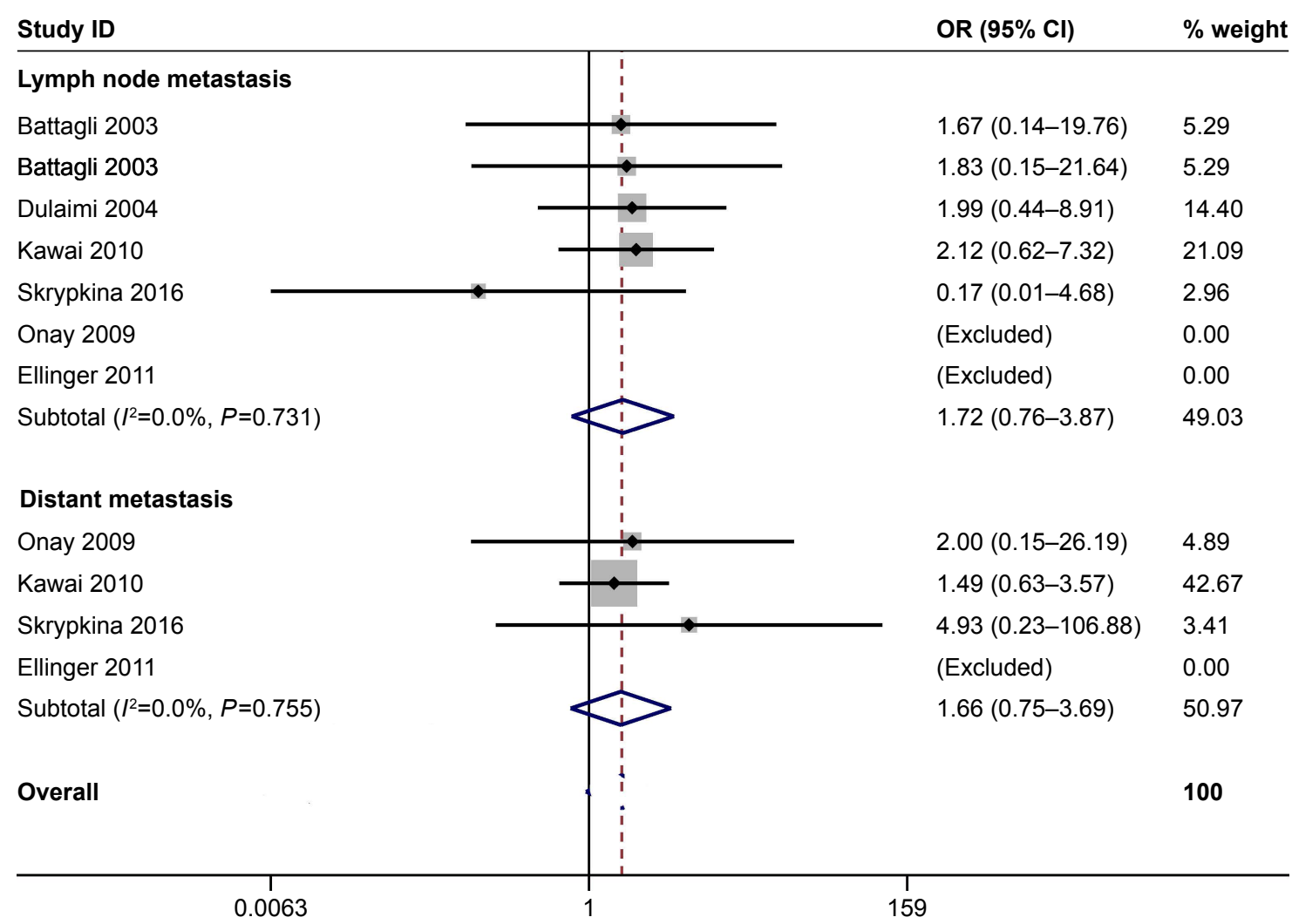

Figure 4 Forest plot of the association of RASSFIA promoter methylation with lymph node metastasis $(\mathrm{OR}=1.72,95 \% \mathrm{Cl}=0.76-3.87, P=0.192)$ and distant metastasis $(\mathrm{OR}=\mathrm{I} .66,95 \% \mathrm{Cl}=0.75-3.69, \mathrm{P}=0.21)$ in $\mathrm{RCC}$.

Note: Weights are from random-effects analysis.

Abbreviation: RCC, renal cell carcinoma.

promoter methylation and $\mathrm{T}$ classification $(\mathrm{OR}=2.66,95 \%$ $\mathrm{CI}=1.11-6.39, P=0.029$; Figure 6). RASSF $1 A$ promoter methylation was also significantly associated with histologic subtypes in eight studies that included 472 patients with RCC $(\mathrm{OR}=2.91,95 \% \mathrm{CI}=1.61-5.23, P<0.001$; Figure 6).

\section{Prognostic role of RASSFIA promoter methylation using multivariate analysis}

Kawai et al reported that RASSF1A promoter methylation was a poor prognostic factor in terms of cancer-specific survival among 179 patients with ccRCC (HR=1.78, 95\% $\mathrm{CI}=1.18-2.78) .{ }^{31} \mathrm{Klacz}$ et al reported that RASSF1A promoter methylation was not associated with overall survival using multivariate analysis among 58 patients with ccRCC. ${ }^{16}$ More studies with large patient population are needed to further investigate the prognostic role of RASSF $1 A$ promoter methylation in RCC.

\section{Publication bias}

There was no evidence of publication bias using Egger's test for the comparison of RCC vs control tissue samples $(P=0.782)$ or in relation to tumor grade $(P=0.547$; Figure 7$)$.

\section{Trial sequential meta-analysis}

As shown in Figures 8 and 9, based on the a priori anticipated information size method for significant results, when cancer was compared with control tissue samples, the cumulative Z-curve crossed the trial sequential monitoring boundary and the required information size (Figure 8), suggesting conclusive results. When cancer was compared with control blood or urine samples, the cumulative Z-curve was more than the conventional boundary, but did not cross the trial sequential monitoring boundary (Figure 8), which suggests that more studies are needed to inform these two results. In relation to tumor grade, clinical stage, and histologic subtypes, the cumulative Z-curve was more than the trial sequential monitoring boundary (Figures 8 and 9), which suggests that additional studies are not necessary. In relation to $\mathrm{T}$ classification, the cumulative $\mathrm{Z}$-curve crossed the conventional boundary, but did not cross the trial sequential monitoring boundary (Figure 8), suggesting that further studies are essential.

\section{TCGA dataset}

After adjusting for tumor stage (stage 3-4 vs stage 1-2) and tumor histology (pRCC vs ccRCC), RASSF1A promoter 


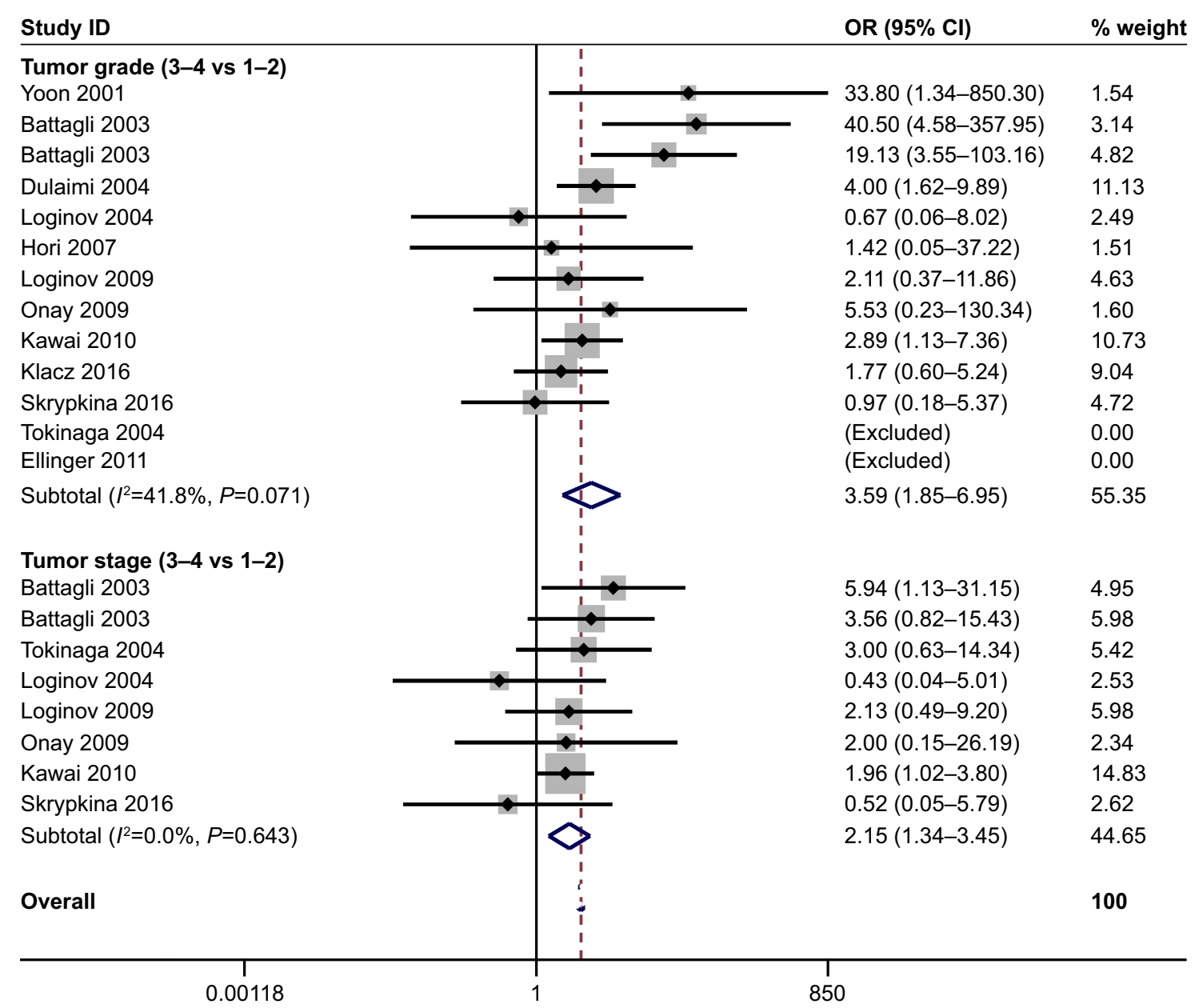

Figure 5 Forest plot of the correlation of RASSFIA promoter methylation with tumor grade $(\mathrm{OR}=3.59,95 \% \mathrm{Cl}=1.85-6.95, P<0.00 \mathrm{I})$ and clinical $\mathrm{stage}(\mathrm{OR}=2.15$, $95 \% \mathrm{Cl}=1.34-3.45, P=0.001)$ in $\mathrm{RCC}$.

Note: Weights are from random-effects analysis.

Abbreviation: RCC, renal cell carcinoma.

methylation was not associated with overall survival using multivariate analysis $(\mathrm{HR}=0.921, P=0.687)$ in 567 RCCs.

RASSF $1 A$ promoter methylation was not significantly linked to gender ( 594 patients: $\mathrm{OR}=1.35,95 \% \mathrm{CI}=0.95-1.91$, $P=0.094$ ), but it did correlate with clinical stage (568 patients: $P=0.023$ ) and tumor histology (594 patients: pRCC vs ccRCC: $\mathrm{OR}=23.19,95 \% \mathrm{CI}=15.07-35.7, P<0.001$; Table 3).

\section{Discussion}

Tumor suppressor genes are commonly inactivated via promoter methylation within the $\mathrm{CpG}$ islands, which may affect several biological processes, including cell proliferation, cell death, cell migration, and cell invasion, and contribute to the initiation and progression of human cancers. ${ }^{46,47}$ Studies have indicated that methylation of the promoter of the tumor suppressor gene RASSF1A reduces its expression, which may play an important role in RCC carcinogenesis. ${ }^{40,43}$ However, potential differences in methylation between RCC and control tissue samples have remained unclear owing to conflicting evidence from previous studies. Two studies showed that RASSF $1 A$ promoter methylation correlated negatively with RCC. ${ }^{33,38}$ Four studies reported no association between RASSF 1A promoter methylation and RCC. ${ }^{18,32,34,36}$ Also, nine other studies showed that RASSF1A promoter methylation correlated positively with RCC. ${ }^{19,37,39-45}$ The present metaanalysis including all eligible publications with large patient populations demonstrated that $R A S S F 1 A$ promoter methylation was notably higher in RCC than in adjacent or normal tissue samples; TSA revealed that the result was conclusive. This suggests that RASSF1A promoter methylation is significantly associated with RCC carcinogenesis.

When RCC was compared with control tissue samples, a subgroup analysis of ethnicity showed that $R A S S F 1 A$ promoter 


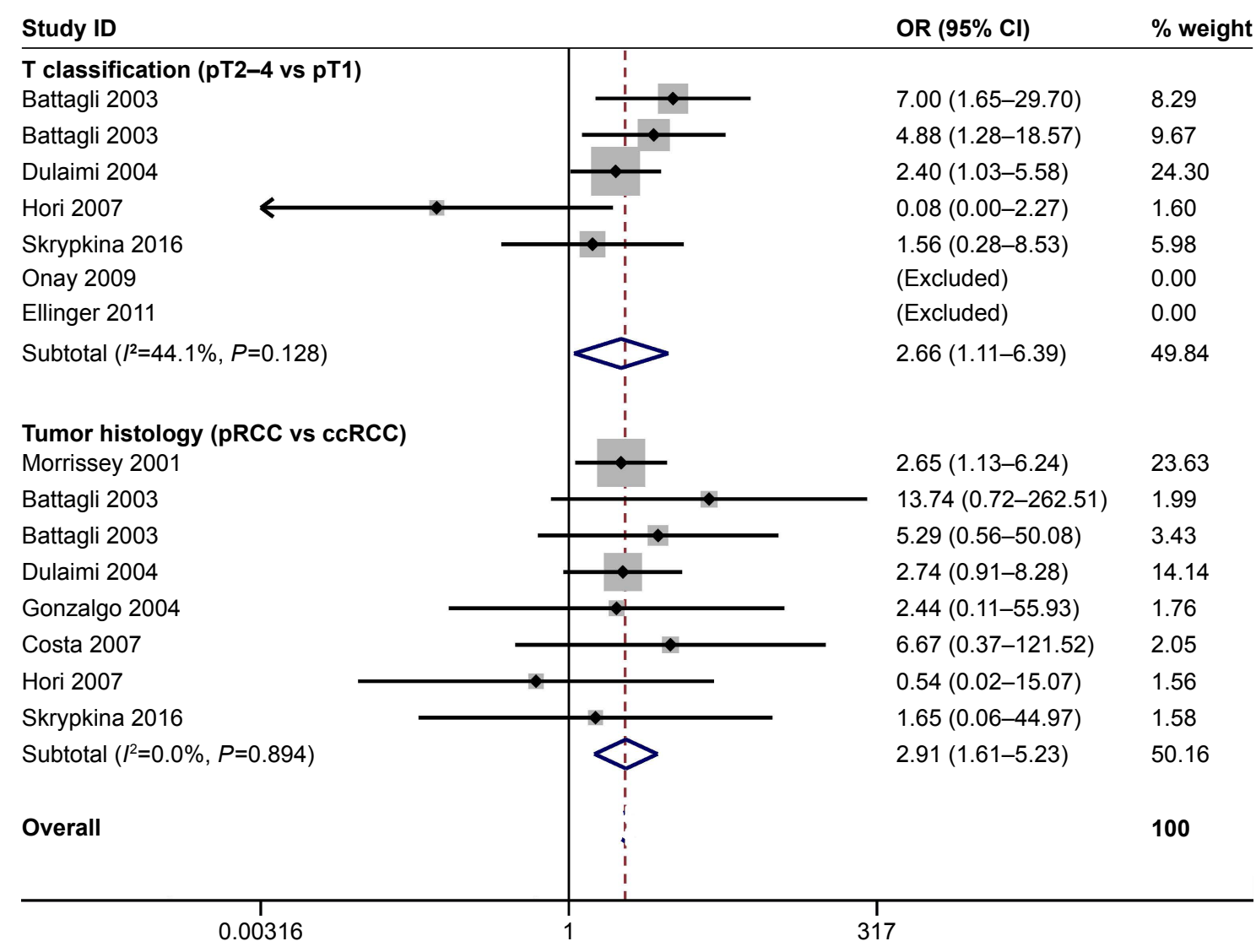

Figure 6 Forest plot of the correlation of RASSFIA promoter methylation with T classification $(\mathrm{OR}=2.66,95 \% \mathrm{Cl}=\mathrm{I} . \mathrm{II}-6.39, P=0.029)$ and histologic subtypes $(\mathrm{OR}=2.9 \mathrm{I}$, $95 \% \mathrm{Cl}=1.6 \mathrm{I}-5.23, \mathrm{P}<0.00 \mathrm{I})$ in $\mathrm{RCC}$.

Note: Weights are from random-effects analysis.

Abbreviations: ccRCC, clear cell RCC; pRCC, papillary RCC; RCC, renal cell carcinoma.

methylation was associated with RCC in Caucasians, but not in Asians, which suggests that only the Caucasian population is susceptible to $R A S S F 1 A$ promoter methylation. A subgroup analysis of detection method demonstrated that RASSF $1 A$ promoter methylation correlated with RCC in the MSP subgroup, but not in the non-MSP subgroup, which indicates that the MSP method may be sensitive to the detection of RASSF $1 A$ promoter methylation. We performed a sensitivity analysis because substantial heterogeneity was measured in the comparison of cancer and control tissue samples. When four studies ${ }^{32,33,36,38}$ were successively removed and the pooled OR was recalculated, remaining significant, there was no evidence of heterogeneity $(P=0.693)$. It is possible that the main cause of heterogeneity in this meta-analysis was contamination of adjacent normal tissue samples by cancer cells in these four studies. In addition, Egger's test showed no publication bias. The relevant analyses supported the stability and credibility of our results.

RASSF $1 A$ promoter methylation was associated with $\mathrm{RCC}$ in blood and urine samples (cancer vs nonmalignant controls), which suggested that RASSF1A promoter methylation may become a promising noninvasive biomarker for the detection of RCC in the future. According to the results of TSA, additional prospective clinical studies with large sample sizes are required to further investigate whether RASSF1A promoter methylation could be used as a biomarker for the diagnosis of RCC based on blood or urine samples.

Finally, we evaluated whether $R A S S F 1 A$ promoter methylation was linked to clinicopathologic characteristics and prognosis in patients with RCC. RASSF1A promoter methylation did not correlate with age, gender, lymph node status, or distant metastasis. Significant relationships were observed between $R A S S F 1 A$ promoter methylation and tumor grade, clinical stage, and $\mathrm{T}$ classification, with methylation notably higher in high-grade vs low-grade tumors, advanced vs early-stage patients, and high (pT2-4) vs low (pT1) T classification. These analyses suggest that $R A S S F 1 A$ promoter methylation may be closely associated with RCC progression. TSA showed that additional studies are essential to 

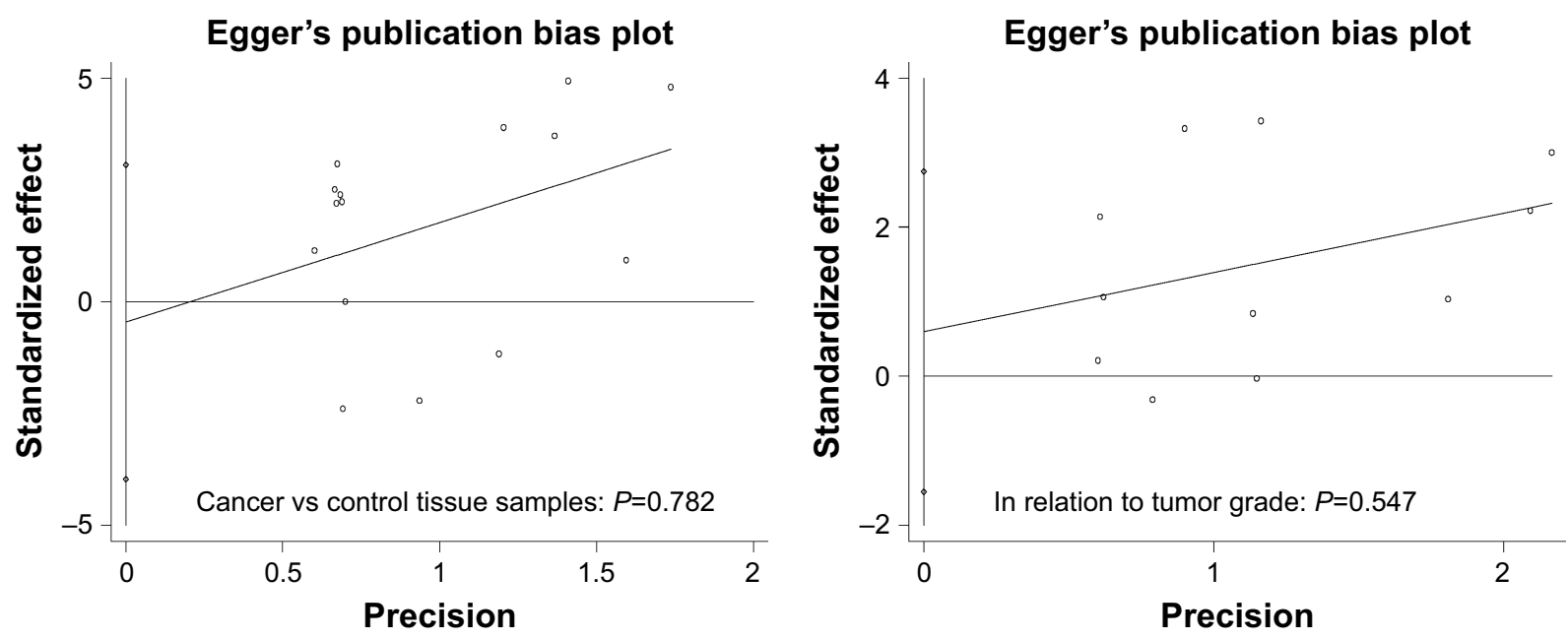

Figure 7 Forest plot of potential publication bias using Egger's test in RCC vs control tissue samples $(P=0.782)$ and in relation to tumor grade $(P=0.547)$. Abbreviation: RCC, renal cell carcinoma.

inform the analyses of $\mathrm{T}$ classification, but that the analyses of tumor grade, clinical stage, and tumor histology were robust. Additionally, TCGA data showed that RASSF1A promoter methylation remained significantly associated with $\mathrm{pRCC}$ vs ccRCC ( $\mathrm{OR}=23.19, P<0.001)$, suggesting that it may play a more important role in the pathogenesis of pRCC. On multivariate analysis, RASSF $1 A$ promoter methylation was associated with poorer cancer-specific survival among 179 patients with ccRCC patients, ${ }^{31}$ but did not correlate with overall survival among 58 patients with ccRCC patients. ${ }^{16}$ Further analysis using TCGA data showed that no correlation was found between RASSF1A promoter methylation and overall survival on multivariate analysis $(\mathrm{HR}=0.921$, $P=0.687$ ) in 567 RCCs. More studies using multivariate analysis will be crucial to confirm the prognostic impact of RASSF 1A promoter methylation on cancer-specific survival.

The current results compare favorably with the previous meta-analyses by $\mathrm{Yu}$ et $\mathrm{a}^{48}$ and Huang et al. ${ }^{49} \mathrm{Yu}$ et al only analyzed whether RASSF1A promoter methylation was correlated with RCC in cancer vs nontumor controls, ${ }^{48}$ and RASSF $1 A$ promoter methylation did not correlate with RCC in tissue samples. ${ }^{48}$ Our result involving a greater number of eligible studies with a larger population (15 studies with 1,296 tissue samples) showed that RASSF1A promoter methylation was significantly associated with $\mathrm{RCC}$ in tissue samples. In addition, Yu et a $\mathrm{l}^{48}$ did not report whether RASSF $1 A$ promoter methylation was linked to clinical features (eg, gender, tumor grade, clinical stage, $\mathrm{T}$ classification, histologic subtypes, lymph node metastasis, and distant metastasis) and did not include an analysis of overall survival. Huang et al only analyzed whether
RASSF1A promoter methylation was linked to tumor stage (five studies with 252 cases) and grade (four studies with 190 cases), showing that RASSF1A promoter methylation had a borderline significant correlation with tumor stage $(P=0.051)$ and a significant association with tumor grade $(P=0.001){ }^{49}$ Our meta-analysis involving more patients suggested that RASSF1A promoter methylation was significantly linked to tumor grade (13 studies with 686 patients with RCC, $P<0.001)$ and clinical stage ( 8 studies with 463 patients with RCC, $P=0.001)$. Additionally, Huang et $\mathrm{al}^{49}$ did not analyze whether RASSF1A promoter methylation was associated with prognosis (cancer-specific survival or overall survival) or other clinical features such as gender, $\mathrm{T}$ stage, and lymph node status.

The current meta-analysis had several limitations. First, the size of the population with blood or urine samples was small. Second, the populations of the included studies mainly consisted of Asians and Caucasians, with limited numbers of other ethnic subgroups, such as Africans. Third, only two studies reported the prognostic role of RASSF1A promoter methylation using multivariate analysis in RCC.

\section{Conclusion}

The present findings show that RASSF $1 A$ promoter methylation correlates with RCC in tissue, blood, and urine samples. RASSF 1A promoter methylation is not linked to age, gender, lymph node status, distant metastasis, or overall survival, but it is associated with tumor grade, clinical stage, T classification, histologic subtypes, and cancer-specific survival on multivariate analysis. Based on TSA, additional studies with large sample sizes are needed to validate these results 

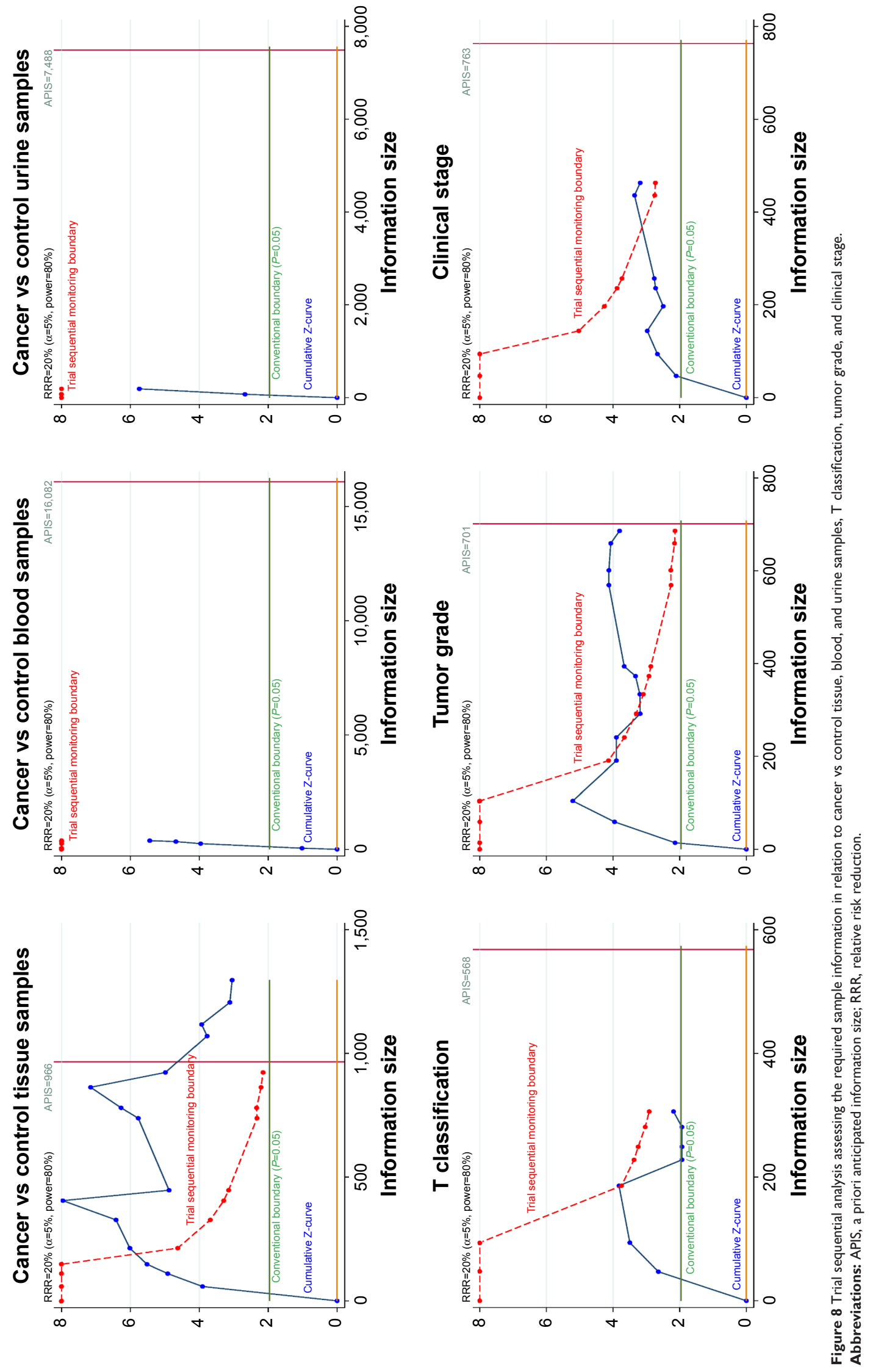


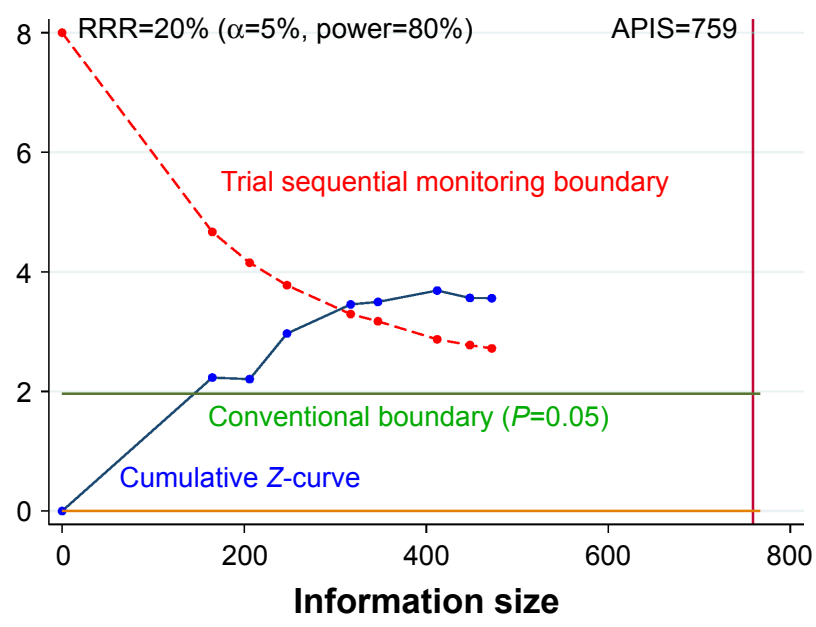

Figure 9 Trial sequential analysis assessing the required sample information in relation to tumor histology.

Abbreviations: APIS, a priori anticipated information size; RRR, relative risk reduction.

Table 3 Association between RASSFIA methylation and clinical pathological characteristics from TCGA dataset

\begin{tabular}{|c|c|c|c|}
\hline Clinical characteristics & $\begin{array}{l}\text { Total } \\
\text { (n) }\end{array}$ & OR with $95 \% \mathrm{Cl}$ & $P$-value \\
\hline Gender (male vs female) & 594 & $1.35(0.95-1.91)$ & 0.094 \\
\hline $\begin{array}{l}\text { Tumor stage (stage } 3-4 \text { vs } \\
\text { stage I-2) }\end{array}$ & 594 & $0.67(0.47-0.94)$ & 0.023 \\
\hline $\begin{array}{l}\text { Tumor histology (papillary } \\
\text { RCC vs clear cell RCC) }\end{array}$ & 568 & 23.19 (15.07-35.7) & $<0.001$ \\
\hline
\end{tabular}

Note: $n$, the number of the study population.

Abbreviations: RCC, renal cell cancer; TCGA, The Cancer Genome Atlas.

in cancer vs control blood and urine samples and to confirm the findings regarding $\mathrm{T}$ classification and prognosis.

\section{Data sharing statement}

All relevant data are included in the paper.

\section{Ethics approval}

Although this study was not primary research involving human samples, our study was a secondary analysis regarding human subject data published in the public domain. For this type of study, formal consent is not required.

\section{Acknowledgment}

This study was supported by the National Science Foundation of Jiangsu Province (Grant No BK20150251), the Youth Medical Talent Project of Jiangsu Province (QNRC2016292), and the China Postdoctoral Science Foundation (Grant No 63, 2018 M632371).

\section{Disclosure}

The authors report no conflicts of interest in this work.

\section{References}

1. Chow WH, Dong LM, Devesa SS. Epidemiology and risk factors for kidney cancer. Nat Rev Urol. 2010;7(5):245-257.

2. Siegel RL, Miller KD, Jemal A. Cancer statistics, 2017. CA Cancer J Clin. 2017;67(1):7-30.

3. Courthod G, Tucci M, Di Maio M, Scagliotti GV. Papillary renal cell carcinoma: a review of the current therapeutic landscape. Crit Rev Oncol Hematol. 2015;96(1):100-112.

4. Lopez-Beltran A, Scarpelli M, Montironi R, Kirkali Z. 2004 WHO classification of the renal tumors of the adults. Eur Urol. 2006;49(5): 798-805.

5. Jonasch E, Gao J, Rathmell WK. Renal cell carcinoma. BMJ. 2014; 349:g4797.

6. Ye M, Huang T, Ni C, Yang P, Chen S. Diagnostic capacity of RASSF1A promoter methylation as a biomarker in tissue, brushing, and blood samples of nasopharyngeal carcinoma. EBioMedicine. 2017;18:32-40.

7. Zhao R, Choi BY, Lee MH, Bode AM, Dong Z. Implications of genetic and epigenetic alterations of CDKN2A (p16(INK4a)) in cancer. EBioMedicine. 2016;8:30-39.

8. Carrió E, Suelves M. DNA methylation dynamics in muscle development and disease. Front Aging Neurosci. 2015;7:19.

9. Okuda H, Toyota M, Ishida W, et al. Epigenetic inactivation of the candidate tumor suppressor gene HOXB13 in human renal cell carcinoma. Oncogene. 2006;25(12):1733-1742.

10. Girgis AH, Iakovlev VV, Beheshti B, et al. Multilevel whole-genome analysis reveals candidate biomarkers in clear cell renal cell carcinoma. Cancer Res. 2012;72(20):5273-5284.

11. Burbee DG, Forgacs E, Zöchbauer-Müller S, et al. Epigenetic inactivation of RASSF1A in lung and breast cancers and malignant phenotype suppression. J Natl Cancer Inst. 2001;93(9):691-699.

12. Vichalkovski A, Gresko E, Cornils H, Hergovich A, Schmitz D, Hemmings BA. NDR kinase is activated by RASSF1A/MST1 in response to Fas receptor stimulation and promotes apoptosis. Curr Biol. 2008;18(23):1889-1895.

13. Donninger H, Vos MD, Clark GJ. The RASSF1A tumor suppressor. J Cell Sci. 2007;120(Pt 18):3163-3172.

14. Rong R, Jiang LY, Sheikh MS, Huang Y. Mitotic kinase Aurora-A phosphorylates RASSF1A and modulates RASSF1A-mediated microtubule interaction and M-phase cell cycle regulation. Oncogene. 2007; 26(55):7700-7708

15. Skrypkina I, Tsyba L, Onyshchenko K, et al. Concentration and methylation of cell-free DNA from blood plasma as diagnostic markers of renal cancer. Dis Markers. 2016;2016:1-10.

16. Klacz J, Wierzbicki PM, Wronska A, et al. Decreased expression of RASSF1A tumor suppressor gene is associated with worse prognosis in clear cell renal cell carcinoma. Int J Oncol. 2016;48(1):55-66.

17. Hoque MO, Begum S, Topaloglu O, et al. Quantitative detection of promoter hypermethylation of multiple genes in the tumor, urine, and serum DNA of patients with renal cancer. Cancer Res. 2004;64(15): 5511-5517.

18. Ellinger J, Holl D, Nuhn P, et al. DNA hypermethylation in papillary renal cell carcinoma. BJU Int. 2011;107(4):664-669.

19. Loginov VI, Khodyrev DS, Pronina IV, et al. Methylation of promoter region of RASSF1A gene and frequencies of allelic imbalances in chromosome 3 critical regions are correlated with progression of clear cell renal cell carcinoma. Mol Biol (Mosk). 2009;43(3):429-438.

20. Zintzaras E, Ioannidis JP. HEGESMA: genome search meta-analysis and heterogeneity testing. Bioinformatics. 2005;21(18):3672-3673.

21. Han S, Zong S, Shi Q, et al. Is Ep-CAM expression a diagnostic and prognostic biomarker for colorectal cancer? A systematic meta-analysis. EBioMedicine. 2017;20:61-69.

22. Higgins JP, Thompson SG, Deeks JJ, Altman DG. Measuring inconsistency in meta-analyses. BMJ. 2003;327(7414):557-560.

23. Lau J, Ioannidis JP, Schmid CH. Quantitative synthesis in systematic reviews. Ann Intern Med. 1997;127(9):820-826.

24. Egger M, Davey Smith G, Schneider M, Minder C. Bias in meta-analysis detected by a simple, graphical test. BMJ. 1997;315(7109):629-634. 
25. Brok J, Thorlund K, Gluud C, Wetterslev J. Trial sequential analysis reveals insufficient information size and potentially false positive results in many meta-analyses. J Clin Epidemiol. 2008;61(8):763-769.

26. Kulinskaya E, Wood J. Trial sequential methods for meta-analysis. Res Synth Methods. 2014;5(3):212-220.

27. Holst LB, Petersen MW, Haase N, Perner A, Wetterslev J. Restrictive versus liberal transfusion strategy for red blood cell transfusion: systematic review of randomised trials with meta-analysis and trial sequential analysis. BMJ. 2015;350:h1354.

28. Wetterslev J, Thorlund K, Brok J, Gluud C. Estimating required information size by quantifying diversity in random-effects model meta-analyses. BMC Med Res Methodol. 2009;9:86.

29. Hauser S, Zahalka T, Fechner G, Müller SC, Ellinger J. Serum DNA hypermethylation in patients with kidney cancer: results of a prospective study. Anticancer Res. 2013;33(10):4651-4656.

30. de Martino M, Klatte T, Haitel A, Marberger M. Serum cell-free DNA in renal cell carcinoma: a diagnostic and prognostic marker. Cancer. 2012;118(1):82-90.

31. Kawai Y, Sakano S, Suehiro Y, et al. Methylation level of the RASSF1A promoter is an independent prognostic factor for clear-cell renal cell carcinoma. Ann Oncol. 2010;21(8):1612-1617.

32. Onay H, Pehlivan S, Koyuncuoglu M, Kirkali Z, Ozkinay F. Multigene methylation analysis of conventional renal cell carcinoma. Urol Int. 2009;83(1):107-112.

33. Costa VL, Henrique R, Ribeiro FR, et al. Quantitative promoter methylation analysis of multiple cancer-related genes in renal cell tumors. BMC Cancer. 2007;7:133.

34. Peters I, Rehmet K, Wilke N, et al. RASSF1A promoter methylation and expression analysis in normal and neoplastic kidney indicates a role in early tumorigenesis. Mol Cancer. 2007;6:49.

35. Hori Y, Oda Y, Kiyoshima K, et al. Oxidative stress and DNA hypermethylation status in renal cell carcinoma arising in patients on dialysis. J Pathol. 2007;212(2):218-226.

36. Gonzalgo ML, Yegnasubramanian S, Yan G, et al. Molecular profiling and classification of sporadic renal cell carcinoma by quantitative methylation analysis. Clin Cancer Res. 2004;10(21):7276-7283.

37. Loginov VI, Maliukova AV, Seregin I, et al. Methylation of the promoter region of the RASSF1A gene, a candidate tumor suppressor, in primary epithelial tumors. Mol Biol (Mosk). 2004;38(4):654-667.
38. Tokinaga K, Okuda H, Nomura A, Ashida S, Furihata M, Shuin T. Hypermethylation of the RASSF1A tumor suppressor gene in Japanese clear cell renal cell carcinoma. Oncol Rep. 2004;12(4):805-810.

39. Dulaimi E, Ibanez de Caceres I, Uzzo RG, et al. Promoter hypermethylation profile of kidney cancer. Clin Cancer Res. 2004;10(12 Pt 1): 3972-3979.

40. Yano T, Ito F, Kobayashi K, et al. Hypermethylation of the CpG island of connexin 32, a candidate tumor suppressor gene in renal cell carcinomas from hemodialysis patients. Cancer Lett. 2004;208(2) 137-142.

41. Battagli C, Uzzo RG, Dulaimi E, et al. Promoter hypermethylation of tumor suppressor genes in urine from kidney cancer patients. Cancer Res. 2003;63(24):8695-8699.

42. Yoon JH, Dammann R, Pfeifer GP. Hypermethylation of the CpG island of the RASSF1A gene in ovarian and renal cell carcinomas. Int $J$ Cancer. 2001;94(2):212-217.

43. Morrissey C, Martinez A, Zatyka M, et al. Epigenetic inactivation of the RASSF1A 3p21.3 tumor suppressor gene in both clear cell and papillary renal cell carcinoma. Cancer Res. 2001;61(19):7277-7281.

44. Duan JM, Zhi LI, Min Z, Zhang JY, Bo P, Huang JH. Abnormal methylation of RASSF1A and BLU genes in renal carcinoma. Acad J Sec Mil Med Univ. 2007;28(10):1068-1071.

45. Yuan JH, Zhou JM, Huang HY. Methylation of $\mathrm{CpG}$ region in promoter region of RASSF1A in renal cell carcinoma. J Trop Med. 2008; 8(6):539-540. Chinese.

46. Shi J, Fu H, Jia Z, He K, Fu L, Wang W. High expression of CPT1A predicts adverse outcomes: a potential therapeutic target for acute myeloid leukemia. EBioMedicine. 2016;14:55-64.

47. Maziveyi M, Alahari SK. Breast cancer tumor suppressors: a special emphasis on novel protein nischarin. Cancer Res. 2015;75(20): 4252-4259.

48. Yu GS, Lai CY, Xu Y, Bu CF, Su ZX. Aberrant methylation of RASSF1A gene contribute to the risk of renal cell carcinoma: a metaanalysis. Asian Pac J Cancer Prev. 2015;16(11):4665-4669.

49. Huang YQ, Guan H, Liu CH, et al. Association between RASSF1A promoter methylation and renal cell cancer susceptibility: a metaanalysis. Genet Mol Res. 2016;15(2). 


\section{Supplementary material}

Table SI Baseline characteristics of the included publications with clinicopathologic features

\begin{tabular}{|c|c|c|c|c|c|c|c|c|c|c|c|}
\hline \multirow[t]{2}{*}{ Author, year } & \multirow[t]{2}{*}{ Country } & \multirow[t]{2}{*}{ Ethnicity } & \multirow[t]{2}{*}{ Method } & \multirow[t]{2}{*}{ Histology } & \multirow[t]{2}{*}{ Sample } & \multicolumn{2}{|c|}{ Case } & \multicolumn{2}{|c|}{$\geq \mathbf{5 0}$ years } & \multicolumn{2}{|c|}{$<\mathbf{5 0}$ years } \\
\hline & & & & & & $\mathbf{M +}$ & Total & M+ & Total & M+ & Total \\
\hline Battagli et al, $2003^{\prime 3}$ & USA & Caucasians & MSP & $\mathrm{RCC}$ & Tissue & 26 & 50 & 22 & 42 & 4 & 8 \\
\hline Battagli et al, $2003^{13}$ & USA & Caucasians & MSP & RCC & Urine & 25 & 50 & 21 & 42 & 4 & 8 \\
\hline Dulaimi et al, $2004^{12}$ & USA & Caucasians & MSP & $\mathrm{RCC}$ & Tissue & 45 & 99 & 40 & 86 & 5 & 13 \\
\hline Hori et al, $2007^{8}$ & Japan & Asians & MSP & $\mathrm{RCC}$ & Tissue & 41 & 42 & 33 & 34 & 8 & 8 \\
\hline Onay et al, $2009^{6}$ & Turkey & Caucasians & MSP & $\mathrm{RCC}$ & Tissue & 11 & 21 & 9 & 18 & 2 & 3 \\
\hline Ellinger et al, 201 $\mathrm{I}^{3}$ & Germany & Caucasians & QMSP & $\mathrm{pRCC}$ & Tissue & 32 & 32 & 26 & 26 & 6 & 6 \\
\hline Skrypkina et al, 2016' & Ukraine & Caucasians & QMSP & $\mathrm{RCC}$ & Blood & 17 & 27 & 13 & 22 & 4 & 5 \\
\hline \multirow[t]{2}{*}{ Author, year } & \multirow[t]{2}{*}{ Country } & \multirow[t]{2}{*}{ Ethnicity } & \multirow[t]{2}{*}{ Method } & \multirow[t]{2}{*}{ Histology } & \multirow[t]{2}{*}{ Sample } & \multicolumn{2}{|c|}{\begin{tabular}{|l|} 
Case \\
\end{tabular}} & \multicolumn{2}{|c|}{ Male } & Fem & ale \\
\hline & & & & & & $\mathbf{M}+$ & Total & M+ & Total & M+ & Total \\
\hline Battagli et al, $2003^{13}$ & USA & Caucasians & MSP & $\mathrm{RCC}$ & Tissue & 26 & 50 & 16 & 34 & 10 & 16 \\
\hline Battagli et al, $2003^{13}$ & USA & Caucasians & MSP & $\mathrm{RCC}$ & Urine & 25 & 50 & 15 & 34 & 10 & 16 \\
\hline Dulaimi et al, $2004^{12}$ & USA & Caucasians & MSP & $\mathrm{RCC}$ & Tissue & 45 & 99 & 29 & 65 & 16 & 34 \\
\hline Hori et al, $2007^{8}$ & Japan & Asians & MSP & $\mathrm{RCC}$ & Tissue & 41 & 42 & 32 & 33 & 9 & 9 \\
\hline Kawai et al, $2010^{5}$ & Japan & Asians & COBRA & $\operatorname{ccRCC}$ & Tissue & 89 & 179 & 69 & 129 & 20 & 50 \\
\hline Ellinger et al, $20 \mathrm{II}^{3}$ & Germany & Caucasians & QMSP & $\mathrm{pRCC}$ & Tissue & 32 & 32 & 26 & 26 & 6 & 6 \\
\hline Klacz et al, $2016^{2}$ & Poland & Caucasians & MSHRM & $\operatorname{ccRCC}$ & Tissue & 23 & 58 & 9 & 30 & 14 & 28 \\
\hline Skrypkina et al, 2016' & Ukraine & Caucasians & QMSP & $\mathrm{RCC}$ & Blood & 17 & 27 & 11 & 13 & 6 & 14 \\
\hline Author, year & Country & Ethnicity & Method & Histology & Sample & Case & & Gra & le 3-4 & Gra & le $1-2$ \\
\hline & & & & & & $\mathbf{M}+$ & Total & $\mathbf{M +}$ & Total & M+ & Total \\
\hline Yoon et al, $200 I^{14}$ & USA & Caucasians & BSQ & RCC & Tissue & 18 & 32 & 6 & 8 & 0 & 6 \\
\hline Battagli et al, $2003^{13}$ & USA & Caucasians & MSP & $\mathrm{RCC}$ & Tissue & 26 & 50 & 18 & 19 & 8 & 26 \\
\hline Battagli et al, $2003^{13}$ & USA & Caucasians & MSP & $\mathrm{RCC}$ & Urine & 25 & 50 & 17 & 19 & 8 & 26 \\
\hline Dulaimi et al, $2004^{12}$ & USA & Caucasians & MSP & $\mathrm{RCC}$ & Tissue & 45 & 99 & 24 & 36 & 17 & 51 \\
\hline Tokinaga et al, 2004"I & Japan & Asians & COBRA & $\operatorname{ccRCC}$ & Tissue & 39 & 50 & 0 & 0 & 20 & 50 \\
\hline Loginov et al, $2004^{10}$ & Russia & Caucasians & MSRA & $\operatorname{ccRCC}$ & Tissue & 50 & 53 & 12 & 13 & 36 & 38 \\
\hline Hori et al, $2007^{8}$ & Japan & Asians & MSP & $\mathrm{RCC}$ & Tissue & 41 & 42 & 13 & 13 & 28 & 29 \\
\hline Loginov et al, $2009^{4}$ & Russia & Caucasians & MSP & $\mathrm{RCC}$ & Tissue & 29 & 39 & 10 & 12 & 19 & 27 \\
\hline Onay et al, $2009^{6}$ & Turkey & Caucasians & MSP & $\mathrm{RCC}$ & Tissue & 11 & 21 & 2 & 2 & 9 & 19 \\
\hline Kawai et al, $2010^{5}$ & Japan & Asians & COBRA & $\operatorname{ccRCC}$ & Tissue & 89 & 179 & 17 & 24 & 69 & 151 \\
\hline Ellinger et al, $20 \mathrm{I}^{3}$ & Germany & Caucasians & QMSP & $\mathrm{pRCC}$ & Tissue & 32 & 32 & 5 & 5 & 27 & 27 \\
\hline Klacz et al, $2016^{2}$ & Poland & Caucasians & MSHRM & $\operatorname{ccRCC}$ & Tissue & 23 & 58 & 15 & 33 & 8 & 25 \\
\hline Skrypkina et al, 2016' & Ukraine & Caucasians & QMSP & $\mathrm{RCC}$ & Blood & 17 & 27 & 5 & 8 & 12 & 19 \\
\hline Author, year & Country & Ethnicity & Method & Histology & Sample & Case & & Stag & e 3-4 & Stag & e I-2 \\
\hline & & & & & & $\mathbf{M +}$ & Total & $\mathbf{M +}$ & Total & M+ & Total \\
\hline Battagli et al, $2003^{\prime 3}$ & USA & Caucasians & MSP & $\mathrm{RCC}$ & Tissue & 26 & 50 & 10 & 12 & 16 & 35 \\
\hline Battagli et al, $2003^{13}$ & USA & Caucasians & MSP & $\mathrm{RCC}$ & Urine & 25 & 50 & 9 & 12 & 16 & 35 \\
\hline Tokinaga et al, 2004" & Japan & Asians & COBRA & $\operatorname{ccRCC}$ & Tissue & 39 & 50 & 5 & 8 & 15 & 42 \\
\hline Loginov et al, 2004 10 & Russia & Caucasians & MSRA & $\operatorname{ccRCC}$ & Tissue & 50 & 53 & 23 & 25 & 27 & 28 \\
\hline Loginov et al, $2009^{4}$ & Russia & Caucasians & MSP & $\mathrm{RCC}$ & Tissue & 29 & 39 & 17 & 21 & 12 & 18 \\
\hline Onay et al, $2009^{6}$ & Turkey & Caucasians & MSP & $\mathrm{RCC}$ & Tissue & 11 & 21 & 2 & 3 & 9 & 18 \\
\hline Kawai et al, $2010^{5}$ & Japan & Asians & COBRA & $\operatorname{ccRCC}$ & Tissue & 89 & 179 & 32 & 52 & 57 & 127 \\
\hline Skrypkina et al, 2016' & Ukraine & Caucasians & QMSP & $\mathrm{RCC}$ & Blood & 17 & 27 & 14 & 23 & 3 & 4 \\
\hline Author, year & Country & Ethnicity & Method & Histology & Sample & Case & & pT2 & & pTI & \\
\hline & & & & & & $\mathbf{M +}$ & Total & & Total & M+ & Total \\
\hline Battagli et al, $2003^{\prime 3}$ & USA & Caucasians & MSP & $\mathrm{RCC}$ & Tissue & 26 & 50 & 14 & 17 & 12 & 30 \\
\hline Battagli et al, $2003^{13}$ & USA & Caucasians & MSP & $\mathrm{RCC}$ & Urine & 25 & 50 & 13 & 17 & 12 & 30 \\
\hline Dulaimi et al, $2004^{12}$ & USA & Caucasians & MSP & $\mathrm{RCC}$ & Tissue & 45 & 99 & 24 & 40 & 20 & 52 \\
\hline Hori et al, $2007^{8}$ & Japan & Asians & MSP & $\mathrm{RCC}$ & Tissue & 41 & 42 & 8 & 9 & 33 & 33 \\
\hline Onay et al, $2009^{6}$ & Turkey & Caucasians & MSP & $\mathrm{RCC}$ & Tissue & 11 & 21 & 11 & 21 & 0 & 0 \\
\hline Ellinger et al, $20 \mathrm{II}^{3}$ & Germany & Caucasians & QMSP & $\mathrm{pRCC}$ & Tissue & 32 & 32 & 13 & 13 & 19 & 19 \\
\hline
\end{tabular}


Table SI (Continued)

\begin{tabular}{|c|c|c|c|c|c|c|c|c|c|c|c|}
\hline \multirow[t]{2}{*}{ Author, year } & \multirow[t]{2}{*}{ Country } & \multirow[t]{2}{*}{ Ethnicity } & \multirow[t]{2}{*}{ Method } & \multirow[t]{2}{*}{ Histology } & \multirow[t]{2}{*}{ Sample } & \multicolumn{2}{|c|}{ Case } & \multicolumn{2}{|c|}{ pT2-4 } & \multicolumn{2}{|c|}{ pTI } \\
\hline & & & & & & $\mathbf{M +}$ & Total & $\mathbf{M +}$ & Total & M+ & Total \\
\hline Skrypkina et al, 2016' & Ukraine & Caucasians & QMSP & $\mathrm{RCC}$ & Blood & 17 & 27 & 7 & 10 & 9 & 15 \\
\hline \multirow[t]{2}{*}{ Author, year } & \multirow[t]{2}{*}{ Country } & \multirow[t]{2}{*}{ Ethnicity } & \multirow[t]{2}{*}{ Method } & \multirow[t]{2}{*}{ Histology } & \multirow[t]{2}{*}{ Sample } & \multicolumn{2}{|c|}{ Case } & \multicolumn{2}{|c|}{ Node +} & \multicolumn{2}{|c|}{ Node- } \\
\hline & & & & & & $\mathbf{M +}$ & Total & $\mathbf{M +}$ & Total & $\mathbf{M +}$ & Total \\
\hline Battagli et al, $2003^{\prime 3}$ & USA & Caucasians & MSP & $\mathrm{RCC}$ & Tissue & 26 & 50 & 2 & 3 & 24 & 44 \\
\hline Battagli et al, $2003^{13}$ & USA & Caucasians & MSP & $\mathrm{RCC}$ & Urine & 25 & 50 & 2 & 3 & 23 & 44 \\
\hline Dulaimi et al, $2004^{12}$ & USA & Caucasians & MSP & $\mathrm{RCC}$ & Tissue & 45 & 99 & 5 & 8 & 36 & 79 \\
\hline Onay et al, $2009^{6}$ & Turkey & Caucasians & MSP & $\mathrm{RCC}$ & Tissue & 11 & 21 & 0 & 0 & 11 & 21 \\
\hline Kawai et al, $2010^{5}$ & Japan & Asians & COBRA & $\operatorname{ccRCC}$ & Tissue & 89 & 179 & 8 & 12 & 81 & 167 \\
\hline Ellinger et al, 201 $\mathrm{I}^{3}$ & Germany & Caucasians & QMSP & $\mathrm{pRCC}$ & Tissue & 32 & 32 & 3 & 3 & 29 & 29 \\
\hline Skrypkina et al, 2016' & Ukraine & Caucasians & QMSP & $\mathrm{RCC}$ & Blood & 17 & 27 & 0 & 1 & 16 & 24 \\
\hline \multirow[t]{2}{*}{ Author, year } & \multirow[t]{2}{*}{ Country } & \multirow[t]{2}{*}{ Ethnicity } & \multirow[t]{2}{*}{ Method } & \multirow[t]{2}{*}{ Histology } & \multirow[t]{2}{*}{ Sample } & \multicolumn{2}{|c|}{ Case } & \multicolumn{2}{|c|}{$\begin{array}{l}\text { Distant } \\
\text { metastasis+ }\end{array}$} & \multicolumn{2}{|c|}{$\begin{array}{l}\text { Distant } \\
\text { metastasis- }\end{array}$} \\
\hline & & & & & & M+ & Total & $\mathbf{M}+$ & Total & M+ & Total \\
\hline Onay et al, $2009^{6}$ & Turkey & Caucasians & MSP & RCC & Tissue & 11 & 21 & 2 & 3 & 9 & 18 \\
\hline Kawai et al, $2010^{5}$ & Japan & Asians & COBRA & $\operatorname{ccRCC}$ & Tissue & 89 & 179 & 14 & 24 & 75 & 155 \\
\hline Ellinger et al, $20 \mathrm{II}^{3}$ & Germany & Caucasians & QMSP & pRCC & Tissue & 32 & 32 & 1 & I & 31 & 31 \\
\hline Skrypkina et al, 2016' & Ukraine & Caucasians & QMSP & $\mathrm{RCC}$ & Blood & 17 & 27 & 3 & 3 & 13 & 22 \\
\hline \multirow[t]{2}{*}{ Author, year } & \multirow[t]{2}{*}{ Country } & Ethnicity & Method & Histology & Sample & Cas & & ccR & & pRC & \\
\hline & & & & & & $\mathbf{M +}$ & Total & $\mathbf{M}+$ & Total & M+ & Total \\
\hline Morrissey et al, 200। ${ }^{15}$ & UK & Caucasians & $\#$ & RCC & Tissue & 59 & 211 & 32 & 138 & 12 & 27 \\
\hline Battagli et al, $2003^{13}$ & USA & Caucasians & MSP & RCC & Tissue & 26 & 50 & 17 & 35 & 6 & 6 \\
\hline Battagli et al, $2003^{13}$ & USA & Caucasians & MSP & RCC & Urine & 25 & 50 & 17 & 35 & 5 & 6 \\
\hline Dulaimi et al, $2004^{12}$ & USA & Caucasians & MSP & $\mathrm{RCC}$ & Tissue & 45 & 99 & 23 & 50 & 14 & 20 \\
\hline Gonzalgo et al, $2004^{9}$ & USA & Caucasians & QMSP & $\mathrm{RCC}$ & Tissue & 30 & 38 & 19 & 21 & 9 & 9 \\
\hline Costa et al, $2007^{7}$ & Portugal & Caucasians & QMSP & RCC & Tissue & 68 & 85 & 42 & 52 & 13 & 13 \\
\hline Hori et al, $2007^{8}$ & Japan & Asians & MSP & $\mathrm{RCC}$ & Tissue & 41 & 42 & 30 & 31 & 5 & 5 \\
\hline Skrypkina et al, 2016' & Ukraine & Caucasians & QMSP & RCC & Blood & 17 & 27 & 15 & 23 & 1 & I \\
\hline
\end{tabular}

Notes: "\#”"stands for bisulfite modification, direct sequencing, and restriction enzyme digestion. T classification, pT; node, lymph node status.

Abbreviations: BSQ, bisulfite sequencing; ccRCC, clear cell RCC; COBRA, combined bisulfite restriction analysis; M, methylation-positive status; MSHRM, methylationsensitive high-resolution melting analysis; MSP, methylation-specific polymerase chain reaction; MSRA, methylation-sensitive restriction enzyme analysis; pRCC, papillary RCC; QMSP, quantitative methylation-specific polymerase chain reaction; RCC, renal cell carcinoma.

\section{References}

1. Skrypkina I, Tsyba L, Onyshchenko K, et al. Concentration and methylation of cell-free DNA from blood plasma as diagnostic markers of renal cancer. Dis Markers. 2016;2016:1-10.

2. Klacz J, Wierzbicki PM, Wronska A, et al. Decreased expression of RASSF1A tumor suppressor gene is associated with worse prognosis in clear cell renal cell carcinoma. Int J Oncol. 2016;48(1):55-66.

3. Ellinger J, Holl D, Nuhn P, et al. DNA hypermethylation in papillary renal cell carcinoma. BJU Int. 2011;107(4):664-669.

4. Loginov VI, Khodyrev DS, Pronina IV, et al. Methylation of promoter region of RASSF1A gene and frequencies of allelic imbalances in chromosome 3 critical regions are correlated with progression of clear cell renal cell carcinoma. Mol Biol (Mosk). 2009;43(3):429-438

5. Kawai Y, Sakano S, Suehiro Y, et al. Methylation level of the RASSF1A promoter is an independent prognostic factor for clear-cell renal cell carcinoma. Ann Oncol. 2010;21(8):1612-1617.

6. Onay H, Pehlivan S, Koyuncuoglu M, Kirkali Z, Ozkinay F. Multigene methylation analysis of conventional renal cell carcinoma. Urol Int. 2009;83(1):107-112.

7. Costa VL, Henrique R, Ribeiro FR, et al. Quantitative promoter methylation analysis of multiple cancer-related genes in renal cell tumors. $B M C$ Cancer. 2007;7:133.

8. Hori Y, Oda Y, Kiyoshima K, et al. Oxidative stress and DNA hypermethylation status in renal cell carcinoma arising in patients on dialysis. J Pathol. 2007;212(2):218-226.
9. Gonzalgo ML, Yegnasubramanian S, Yan G, et al. Molecular profiling and classification of sporadic renal cell carcinoma by quantitative methylation analysis. Clin Cancer Res. 2004;10(21):7276-7283.

10. Loginov VI, Maliukova AV, Seregin I, et al. Methylation of the promoter region of the RASSF1A gene, a candidate tumor suppressor, in primary epithelial tumors. Mol Biol. 2004;38(4):549-560.

11. Tokinaga K, Okuda H, Nomura A, Ashida S, Furihata M, Shuin T. Hypermethylation of the RASSF1A tumor suppressor gene in Japanese clear cell renal cell carcinoma. Oncol Rep. 2004;12(4):805-810.

12. Dulaimi E, Ibanez de Caceres I, Uzzo RG, et al. Promoter hypermethylation profile of kidney cancer. Clin Cancer Res. 2004;10(12 Pt 1): 3972-3979.

13. Battagli C, Uzzo RG, Dulaimi E, et al. Promoter hypermethylation of tumor suppressor genes in urine from kidney cancer patients. Cancer Res. 2003;63(24):8695-8699.

14. Yoon JH, Dammann R, Pfeifer GP. Hypermethylation of the CpG island of the RASSF1A gene in ovarian and renal cell carcinomas. Int $J$ Cancer. 2001;94(2):212-217.

15. Morrissey C, Martinez A, Zatyka M, et al. Epigenetic inactivation of the RASSF1A 3p21.3 tumor suppressor gene in both clear cell and papillary renal cell carcinoma. Cancer Res. 2001;61(19):7277-7281. 


\section{Publish your work in this journal}

OncoTargets and Therapy is an international, peer-reviewed, open access journal focusing on the pathological basis of all cancers, potential targets for therapy and treatment protocols employed to improve the management of cancer patients. The journal also focuses on the impact of management programs and new therapeutic agents and protocols on

patient perspectives such as quality of life, adherence and satisfaction. The manuscript management system is completely online and includes a very quick and fair peer-review system, which is all easy to use. Visit http://www.dovepress.com/testimonials.php to read real quotes from published authors.

Submit your manuscript here: http://www.dovepress.com/oncotargets-and-therapy-journal 